\title{
Impact of industrial effluent on macrobenthic diversity: A case study of Thannirbhavi and Chitrapur coastal area of Mangalore
}

\author{
Kumari M. $凶$
}

Received: 16.05 .2020

Revised: 08.06.2020

Accepted: 12.06.2020

\begin{abstract}
In view of understanding the impact of effluents and on the occurrence and distribution of macrobenthic organisms, an investigation has been carried out for a period of 8 months from October 2006 to May 2007 in the nearshore water of Thannirbhavi and Chitrapur receiving treated industrial effluents and Bengre coast having estuarine influences. The quality composition of benthic organism revealed the presence of hydroids such as Obeliasp,Cordylophorasp and companularia sp. Polychaetes belonging to 15 diferent families have been identified and their distribution revealed variation with respect to the type of the effluents. 24 different types of molluscss have been identified and their occurrence and distribution was found to be related to type of sediment and the quality of the effluents. Bulks of crustaceans were formed mainly due to species of Gammarus, Caprellids and Tanaidaceans. The great abundance and diversity of benthic organisms was observed in the Thannirbhavi receiving effluents from a fertilizer industry, when compare to the Chitrapur receiving treated effluents from a dye industry and an oil refinery industry. Silty-clayey sediment harbored higher density of polychaetes where as sandy-silty sediment supported greater abundance of molluscs.
\end{abstract}

Key Words: Coastal zone, Industrial effluent, Macrobenthos, Pollution, Sediment characteristics

\section{Introduction}

The coastal region is always subjected to influences of land fresh water influx, cyclone and severe wave action which makes this region most unstable. Equally important are the human induced impact brought through industrial mining, oil exploration, port activities, mineral exploration and dumping of pollutants. The natural changes and manmade activities are constantly bringing greater pressure to this important realm of the ocean. Among the three major communities of marine environment the study of benthic communities are found to be better indicator of pollution (Venugopal et al., 1982 and Satyanarayan et al., 1994; Gopalkrishnan and Nair, 1998). Studies on benthos in the recent years have assumed greater importance since they not only form an important link in food chain but also act as an index to identify any deviation from the natural characteristics of an ecosystem. A regular monitoring and analysis of benthic communities will serve as good index for understanding the changes in space and time. Urbanization and increased industrialization along the Karnataka

\section{Author's Address}

Department of Aquatic Environment Management, College of Fisheries Mangalore -575002

E-mail.: madhu.pinki.2016@gmail.com coast has been growing on for the past two decades. As a result the coastal water of this region receiving not only increased load of domestic sewage but also various kinds of effluent of different industries. In order to understand the impact of above said factors on benthic communities three regions were selected for study i.e. Bengre, Thannirbhavi and Chitrapur along the coastal waters of Mangalore. Bengre region having estuarine influences and receiving load of domestic sewage and the Thannirbhai and Chitrapur regions having influences of major industries. Thannirbhavi is the region receiving treated effluents from Mangalore Chemical Fertilizers (MCF) a fertilizer industry and the Chitrapur regions receiving treated effluents from Manglore Refinery Petrolium Limited (MRPL) and Baddish Analine Soda Factory (BASF) a soda factory. The present study is aimed to understand occurrence, distribution and diversity of macrobenthic organism along these regions. The study also aimed to understand the present sedimentological status of the area and its possible effect on quality composition of benthos. Studies on benthos along this coast have been carried out by Harkantra (1982), Devassy and Gopinath (1970) and Venkatesh and Reddy (1987) which revealed a 
clear-cut seasonal and spatial variation in relation to sediment characteristics.

\section{Material and Methods}

Monthly sampling was carried out from October 2006 to May 2007 in coastal waters of Arabian Seaoff Bengre, Thannirbhavi and Chitrapur. The observations were made along three section at $5 \mathrm{~m}$ and $10 \mathrm{~m}$ depth contour, first at $5 \mathrm{~m}$ depth contour$\mathrm{B} 1$ (Bengre), T1(Thannirbhavi) and $\mathrm{C} 1$ (Chitrapur) and second at $10 \mathrm{~m}$ depth contour- B2, T2 and C2 (fig: 1). Sediment samples were collected using Peterson grab and kept in clean polythene bags. The sample were divided into two portion in laboratory, one portion was shade dried, weighed ,wet sieved through a $0.0625 \mathrm{~mm}$ sieved to separate sand from silt and clay fraction, then the sand fraction was dried, weighed and percentage was determined. Further the percentage of silt and clay were determined by employing pipette analysis
(Buchanan and Kain, 1971) and the portion was washed repeatedly using tap water and then distilled water to remove the adhered salts. After washing these samples were shade dried pulverized to fine size and sieved through a standard test sieve. The organic carbon of sediment was determined by method given by El-Wakeel and Riley (1957). The results were represented in percentage of organic carbon in dry sediment. For collecting macrobenthos Petersons' type of grab bites of $0.1 \mathrm{~m}^{2}$ were used. The samples were sieved through $0.5 \mathrm{~mm}$ mesh size to collect macrobenthos. Benthos were sorted out and identified up to family/genera level. The numerical abundance of macrobenthos was expressed in terms of $\mathrm{No} / \mathrm{m}^{2}$ and percentage of total abundance. Hydroids and egg cases abundance were represented as $\operatorname{rare}(\mathrm{R}), \operatorname{common}(\mathrm{C})$ and very common (VC). Temporal and spatial varition of total macrobenthos were tested using two way ANOVA.

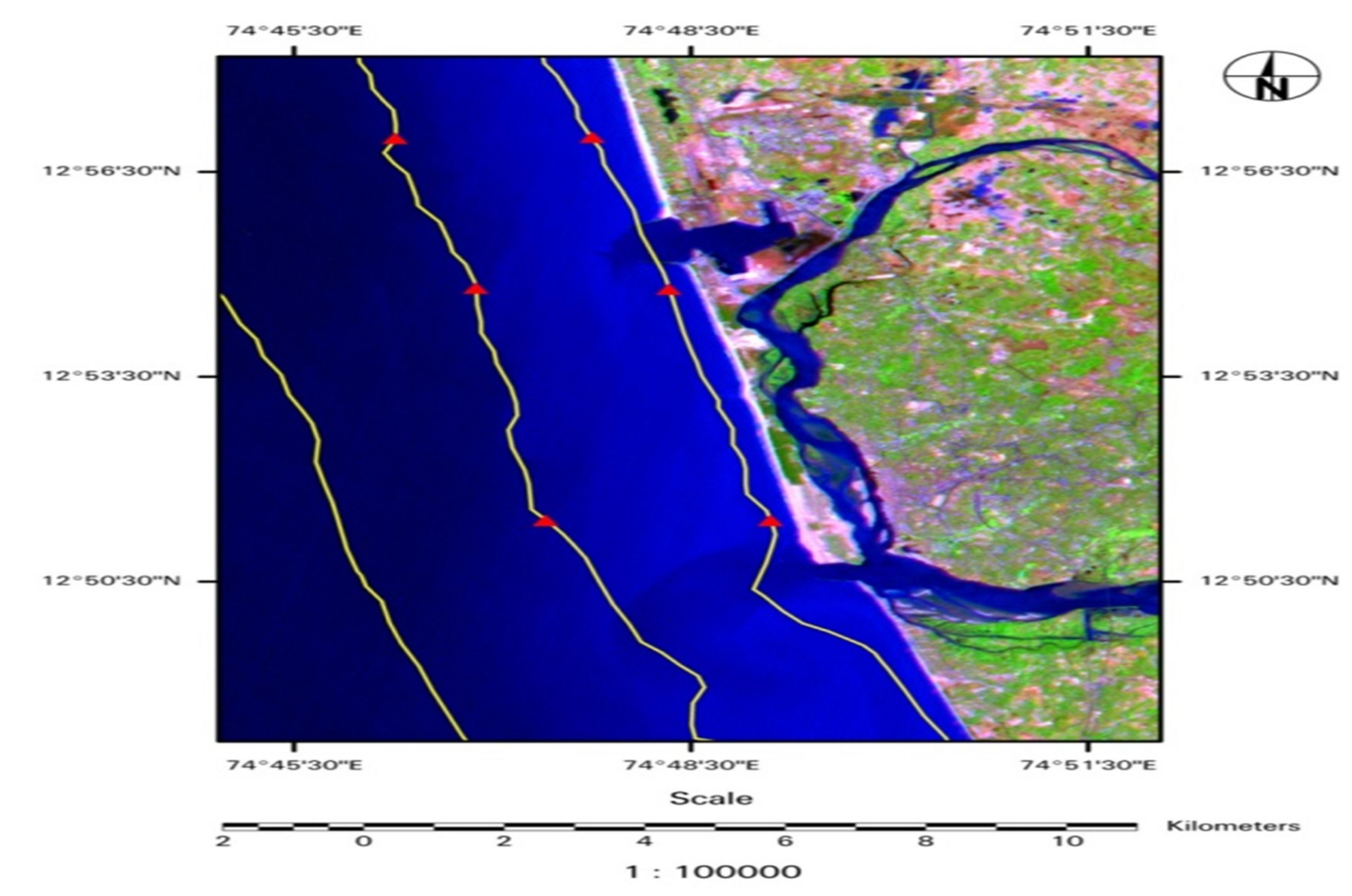

Fig 1. Map showing location of sampling station. 


\section{Results and Discussion Macrobenthos}

Spatial and temporal distribution of macrobenthos in the terms of their numerical abundance $\left(\mathrm{No} / \mathrm{m}^{2}\right)$ at different station along Bengre, Thannirbhavi and Chitrapur section are depicted in fig: 2 (B1, T1, C1 and B2, T2, C2). The quality composition of macrobenthos were represented by six different groups namely Echiuroids, Sipunculoids, Polychaetes, Crustacean, Molluscs and Echinodermata and their number varied from 90 to $15100 \mathrm{No} . \mathrm{m}^{2}$. Hydroids and egg cases abundance were found very common, common and rare at different stations. In the present study macrobenthic organigms have exhibited a clearcut seasonal and spatial variation. The macrobenthic along Bengre coast fluctuated between 810 and $1500 \mathrm{No} . / \mathrm{m}^{2}$, at Thannirbhavi coast it varied from 740 to 7800 No. $/ \mathrm{m}^{2}$ while at Chitrapur the values varied from 90 to1990 No. $/ \mathrm{m}^{2}$. In the present study numerical density of macrobenthos was found to be much higher than the observation made by Jayraj (1982), Prabhu (1992) and Laxmipathi (2001) in the same area. The distribution of macro benthos at 5 and 10 meters depths contour along the coast of Bengre and Chitrapur are depicted in Figure 2. From the Figure 2 it becomes evident that at 5 meters depth the population of Polychaets were most dominant at Bengre which was followed mainly by Bivalves, Gastropods and Crustaceans. At the same depth contour along the coast of Thannirbhavi the dominance of Polychaets reduced at higher level which was followed mainly by Bivalves, Gastropods, Scaphopeds and Crustaceans.While along Chitrapur coast the dominance of Polychaets was present only in October and November and during later half of Post monsoon, the benthic population was dominated by bivalves and Gastropods which was followed by Polychaeta and Scaphopeds whereas at 10 meters depth along Bengre coast the dominance of polychaets was observed (except in the month of November) which was followed by Bivalves in October, November and Gastropods in December, January. At Thannirbhavi the dominance of polychaets was observed (except in the month of December) which was followed by Bivalves, Gastropods and Scaphopods while at Chitrapur dominance of gastropods was observed through post monsoon except in the month of November which was followed by polychaets, Bivalves, Scaphopods and Echinoderms. From the fig: 2 it becomes evident that the diversity of macrobenthic fauna at 5 meters depth along Bengre coast was less followed by Chitrapur and Thannirbhavi. Along 10 meters depth in comparison with 5 meters depth the diversity of macro benthos at Bengre though higher than 5 meters depth and maintains the same diversity as that of Thannirbhavi during first half of post monsoon (October and November) whereas in second half numerical abundance of benthos was lesser at Thannirbhavi. Along Chitrapur along same contour depth the diversity was less compared to Thannirbhavi and Bengre during first half of post monsoon, while during the second half diversity of benthos was higher in Chitrapur than that of Thannirbhavi. From the fig: 2 it was evident that during first half during first half of premonsoon season the benthic diversity was higher at Bengre followed by Thannirbhavi and Chitrapur at $5 \mathrm{~m}$ depth contour. While at $10 \mathrm{~m}$ depth contour along Thannirbhavi population diversity was higher followed by Chitrapur and Bengre. During second half of premonsoon Bengre supported highly diversed macrobenthic population which was followed by Thannirbhavi and Chitrapur (expect station C1). In the present study most of the time hydroids were found to be belonging to genera Obelia, Cordylophora and Campanularia and rarely colonies of Hydractina were observed in the samples. Spatial distribution revealed stations located along Bengre coast supported higher colonies of hydroids in post and pre monsoon seasons. Along Thannirbhavi section, very few colonies were observed and along Chitrapur hydroids were absent almost throughout the study period. Ansari et al. (1977), Parulekar and Ansari (1981), Mohan (1999), Lakshmipathi (2001) could not observe colonies of hydroids in the benthic samples. However studies carried out by Menon et al. (1979) hydroids to be very common on the glass panel exposed to sea water along the coast. Parulekar et al. (1980) and Prabhu et al. (1993) indicated the presence of hydroids in the backwaters of Kerala and in the inshore waters of Gangolli. A very rare and total absence of hydroids along the Chitrapur coast could be due to incapable of species to colonies in the inshore waters due to impact of industrial effluents. 


\section{Kumari M.}

B1

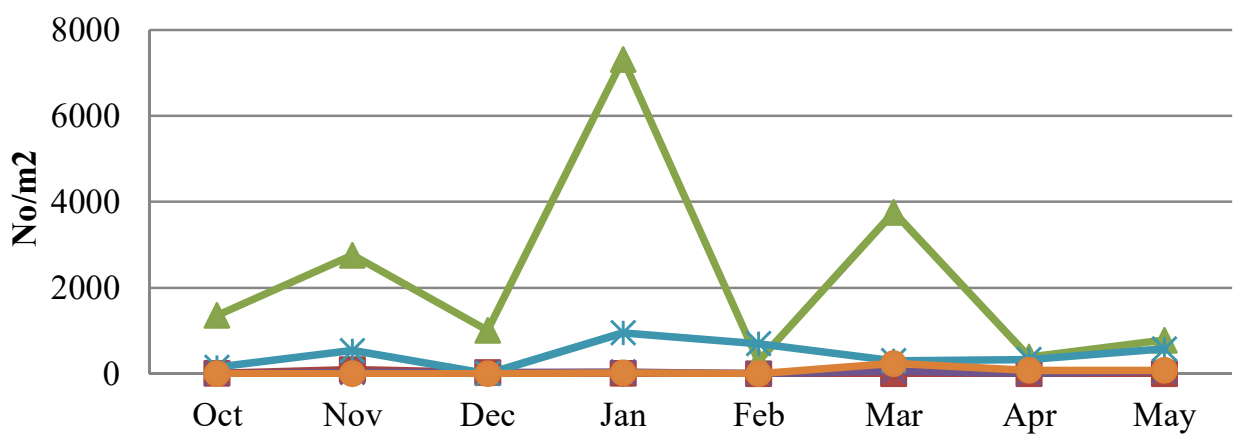

$\checkmark$ Echiuroidea

- Sipunculoidea

- Polychaeta

$\leftarrow$ Crutaceans

* Molluscs

- Echinodermata

\section{T1}

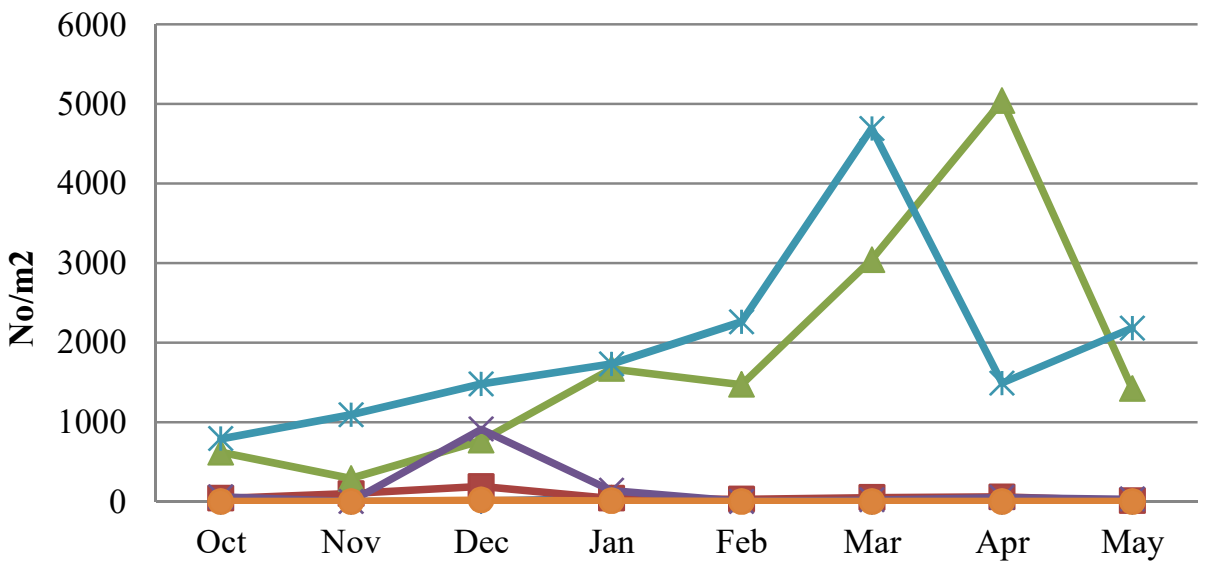

$\neg$ Echiuroidea

-Sipunculoidea

$\longleftarrow$ Polychaeta

CruStaceans

*Molluscs

- Echinodermata

\section{C1}

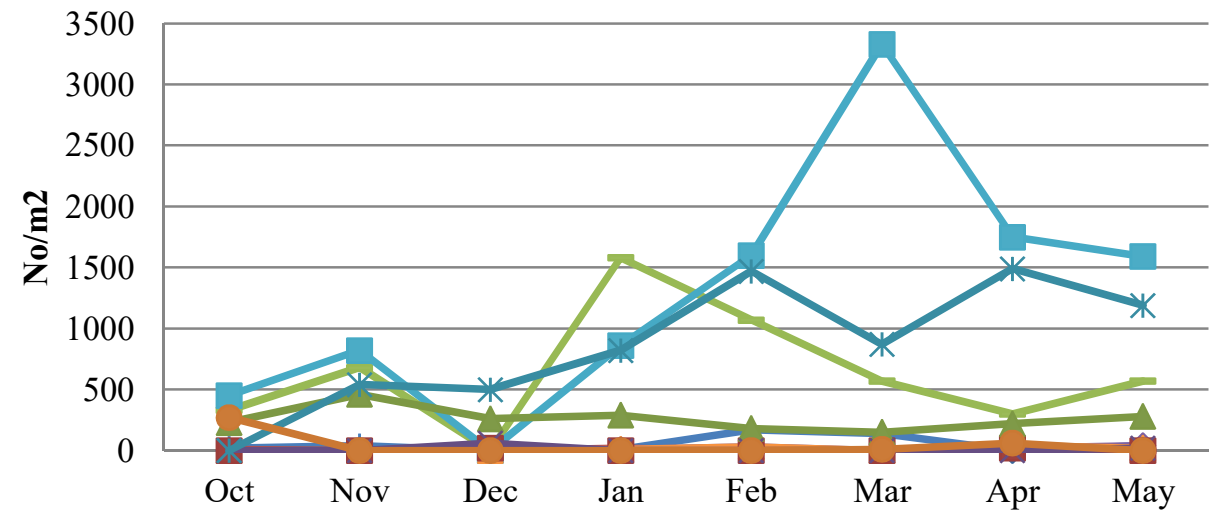

+ Echiuroidea

Sipunculoidea

Polychaeta

$\sim$ Crutaceans

- Molluscs

- Echinodermata

$\neg$ Echiuroidea

-Sipunculoidea

Environment Conservation Journal 
B2

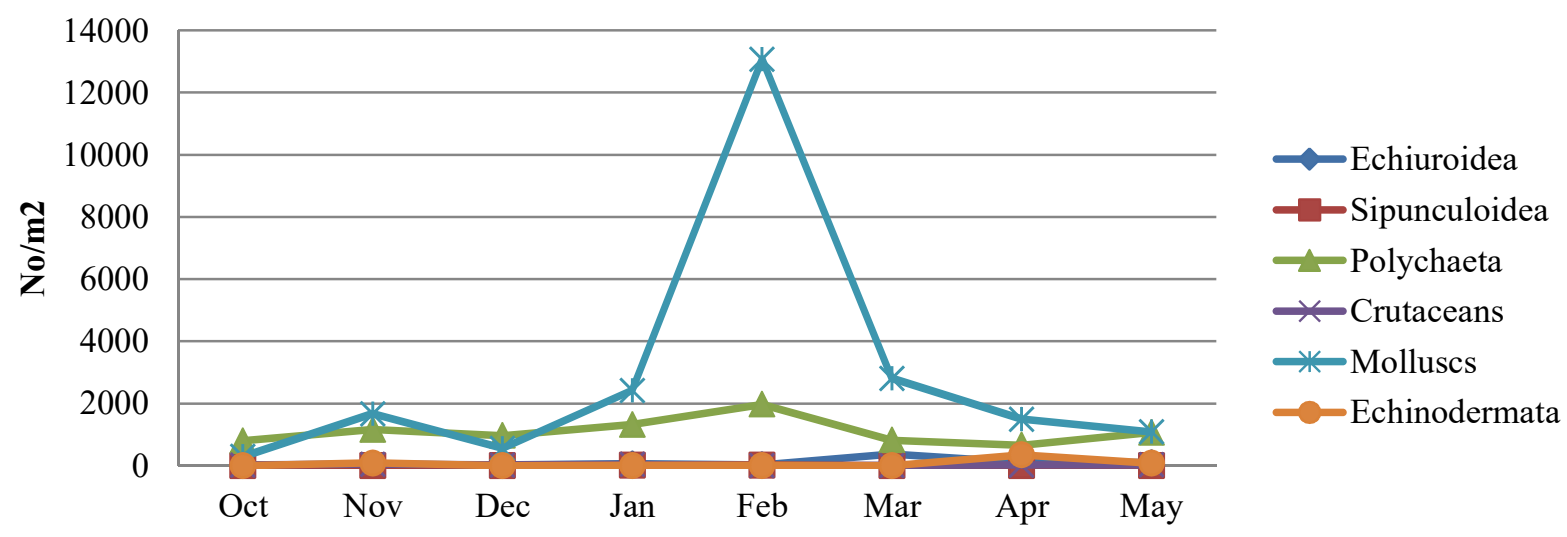

T2

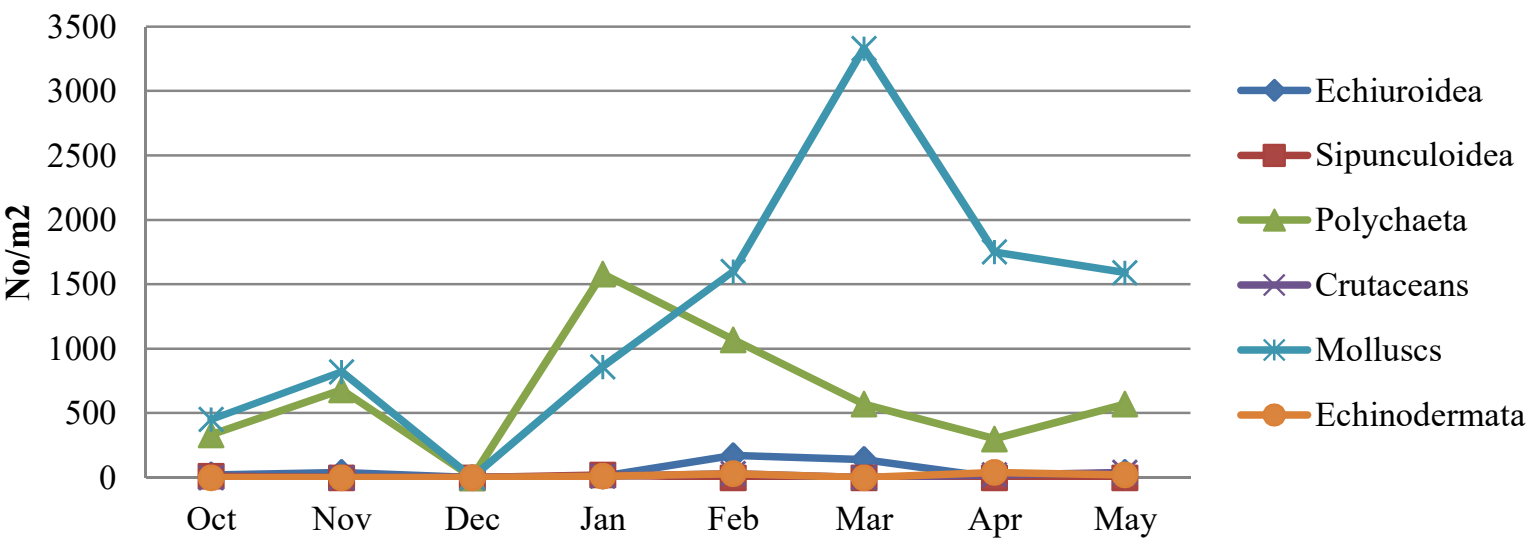

\section{C2}
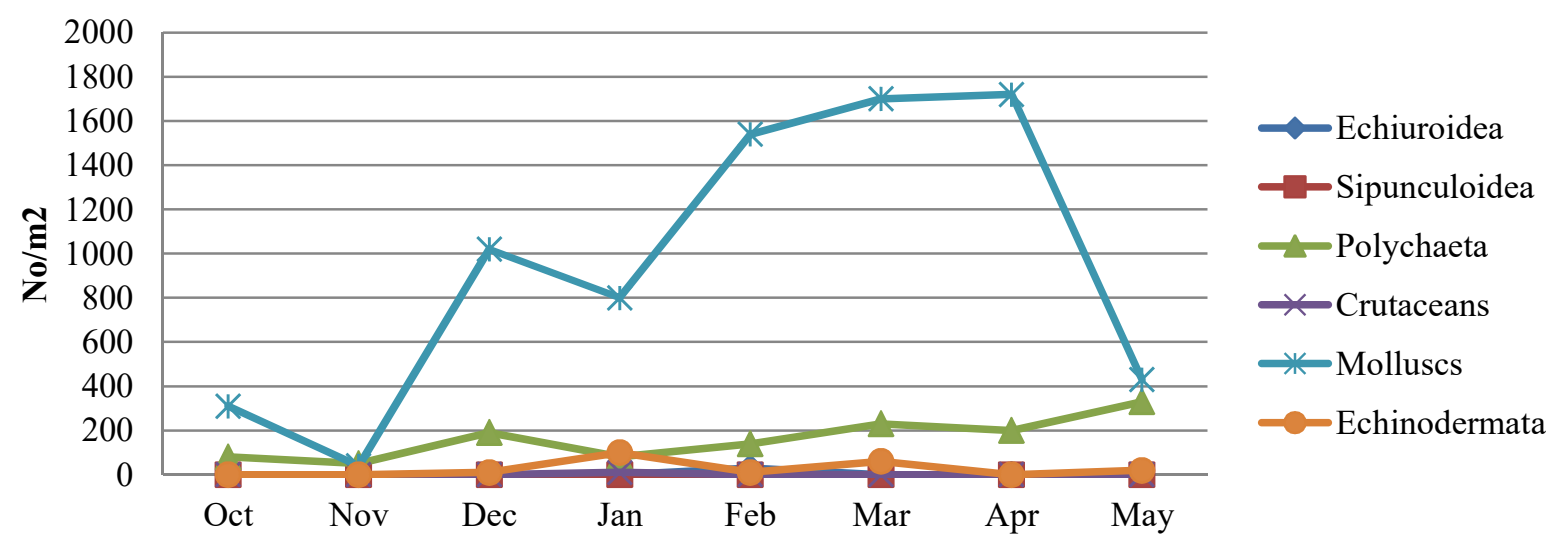

Fig 2. Monthly variation of macrobenthos along Bengre, Thannirbhavi and Chitrapur at $5 \mathrm{~m}$ and $10 \mathrm{~m}$ depth contour. 


\section{Kumari M.}

From the fig: 2 it becomes very clear that the stations along Bengre coast supported high numbers of Echuroids and Sipunculoidae and they were less along Thannirbhavi coast, rare in the stations located along Chitrapur coast. The seasonal distribution revealed greater abundance of Echuroids in the pre monsoon whereas Sipunculoidae were abundant in post monsoon season. Harkantra and Parulekar (1994) recorded $1.23 \%$ of Sipunculoidae and $7.6 \%$ of Echuroids to the total macrobenthos in the Rajapur bay in central west coast of India. It is interesting to note that in present study Echuroids were $9.45 \%$ and Sipunculoidae were $6.75 \%$ to the total macrobenthos. From the data gathered it was revealed that these two groups preferred salty clayey substratum than that of sandy silty substratum, and further higher numbers of these two groups coincided with greater percent of organic carbon in the sediments. Polychaetes belonging to 15 different families were observed they are Spionidae, Glyceridae, Maldanidae, Nephthydidae, Nereidae, Eunicidae, Capitellidae, Sabellaria, Serpulidae, Sabellariidae, Cirrtulidae, Opheliidae, Polydoridae, Terebellidae and Tomopteridae. It is evident that Polychaets population during post monsoon season at Bengre varied from $1010 \mathrm{No} / \mathrm{m}^{2}$ to $7320 \mathrm{No} \mathrm{m}^{2} /$ at $5 \mathrm{~m}$ depth contour, and at $10 \mathrm{~m}$ depth it varied from 800 to $1320 \mathrm{No} / \mathrm{m}^{2}$. At Thannirbhavi it ranged from 290 to $1670 \mathrm{No} / \mathrm{m}^{2}$ at 5 meters and at 10 meter the numbers fluctuated from 0 to $1580 \mathrm{No} / \mathrm{m}^{2}$. Along Chitrapur, the Polychaets numbers fluctuated between 230 to $460 \mathrm{No} / \mathrm{m}^{2}$ and at 10 meter depth they ranged from 50 to $190 \mathrm{No} / \mathrm{m}^{2}$. Thus it can be stated that by and large Polychaets population was higher along Bengre coast followed by Thannirbhavi and Chitrapur. During pre monsoon season, at Bengre Polychaets population varied from 290 to $3760 \mathrm{No} / \mathrm{m}^{2}$ at 5 meter depth, and at 10 meter values ranged from 660 to $1970 \mathrm{No} / \mathrm{m}^{2}$. At Thannirbhavi Polychaets numbers varied from 1420 to $5040 \mathrm{No} / \mathrm{m}^{2}$ at 5 meter and at 10 meters the numbers ranged from 300 to $1070 \mathrm{No} / \mathrm{m}^{2}$. Along Chitrapur Polychaets varied from 150 to $280 \mathrm{No} / \mathrm{m}^{2}$ at 5 meters and at 10 meters 140 to $330 \mathrm{No} / \mathrm{m}^{2}$. It is clear from the data during pre monsoon season Polychaets populations were high at 5 meter depth than 10 meter along all the three sections. However a reducing trend of Polychaets population from
Bengre to Chitrapur but it was not so along 10 meter depth. Dominance of Polychaets along west coast of India were observed by Ansari et al. (1977), Pillai (1977), Harkantra et al. (1980), Parulekar and Ansari (1981), Jayaraj (1982) observed greater number of Polychaets in the coastal waters of Mangalore. Mohan (1999) observed observed family Glyceridae, Maldanidae, Nephthydidae, Onuphidae, Lumbriconeridae, Spionidae and Laxmipathi (2001) observed Maldanidae, Neridae, Nephthydidea, Glyceridae in same area. Jayraj et al. (2007) recorded the dominance of polychaete belonging to the class Sedentarian in Northwest shelf of India. Along the south west coast of Indian Ocean the dominance of Spionidae and Cpitellidaelidae was observed. In the present study most of the Polychaets were found to be belonging to class sedentarian and most of them where the deposit feeder have the capacity to build arnaceous tube. It is interesting to note a greater abundance of Polychaets belonging to family capitelladae which was not recorded by earlier authors who have worked in the same area. Occurrence and abundance of Polychaets belonging to this family was used as indicator species of organic pollution. In the present study Capatelledae Polychaets were abundant wherever the organic carbon percent was higher in the sediment. In the present study, crustaceans were third abundant group in the macrobenthic population. This group mainly consisted of individual belong to family Tanidacea Gammanidae, Caprellidae, Ocypodidae and Cumaceans. The density of crustaceans varied from 0 to $60 \mathrm{No} / \mathrm{m}^{2}$ at $5 \mathrm{~m}$ depth along Bengre and at $10 \mathrm{~m}$ depth it varied from 0 to $50 \mathrm{No} / \mathrm{m}^{2}$, Along Thannirbhavi at $5 \mathrm{~m}$ depth density varied from 0 to $910 \mathrm{No} / \mathrm{m}^{2}$ and at $10 \mathrm{~m}$ depth it varied from 0 to 40 $\mathrm{No} / \mathrm{m}^{2}$ no and along Chitrapur at $5 \mathrm{~m}$ depth varied from 0 to $60 \mathrm{No} / \mathrm{m}^{2}$ whereas at $10 \mathrm{~m}$ depth it varied from 0 to $10 \mathrm{No} / \mathrm{m}^{2}$. The station located at Chitrapur registered very low numbers of crustaceans when compared to other to station. Ansari (1977) recorded fairly good numbers of Gammaridae and Caprillidae , Harkantra (1980) documented higher contribution to an extent of $17.26 \%$ in shelf regions of west coast of India Devassy et al., (1987) recognized the presence of Amphipods and Tanaidaceans in the inshore waters of Vezhenjam. Menon et al. (1979) recorded 2.4\% contribution along the coast. Prabhu (1992) 
recorded two species of crab and very low percentage of Gammarids in the inshore waters of Gangolli, Dakshina Kannada. Laxmipathy (2001) observed only shrimps, crabs and stomatopods in the benthic samples collected from the inshore waters of Mangalore. Mohan (1999) could observe few crabs and shrimps in the coastal waters of Chitrapur. However Baban et al., (2002) and Jayaraj et al., (2007) observed fairly good numbers of Amphipods in the coastal waters of Dhabol, North West Indian shelf respectively. While comparing the works carried out by many authors who have worked in the same area, the foremeost investigation revealed the abundance of Crustaceans consisting mainly of species belonging to Tanaidacea and Gammirids. It is interesting to note that during the present study higher contribution of Crustaceans population coincided with low dissolved oxygen content in the near bottom waters. This clearly shows that the amphipods and tanideceans tolerate very low dissolved oxygen condition. Further the crustacean's population was lower when the polycheats population is higher. This suggests that the carnivorous nature of the Polychaets may not be allowing the Crustaceans to establish in the area. Similar opinion was expressed by Harkantra (1982) and Parulikar and Ansari (1981) and Prabhu (1992). In the present investigation, the phylum Mollusca was represented mainly by three classes such as Scaphopoda, Gastropoda and Bivalvia. Scaphopoda was represented by Dentallium and Gastropoda was represented by species belonging to 12 genera. While Bivalva was represented by species belonging to 11 genera. In the present investigation percentage contribution of molluscss to the total benthos varied both in space and time. Along Bengre coast at $5 \mathrm{~m}$ depth the number varied from 0 to $90 \mathrm{t} \mathrm{m}^{2}$ at $10 \mathrm{~m}$ depth it varied from 300 to $13070 / \mathrm{m}^{2}$. Along Thannirbhaviat $5 \mathrm{~m}$ depth number varied from 790 to $4690 / \mathrm{m}^{2}$ and at $10 \mathrm{~m}$ depth varied from 450 to $3300 / \mathrm{m}^{2}$. Along Chitrapur at $5 \mathrm{~m}$ depth number varied from 0 to $1490 / \mathrm{m}^{2}$ and at $10 \mathrm{~m}$ varied from 40 to $1720 / \mathrm{m}^{2}$. Kurian (1971) recorded maximum biomass to the extent of $10 \mathrm{~kg}$ live weight including shells in Cochin back waters. Ansari et al., (1977) while invetigating on shallow waters benthos from Vengurla to Mangalore documented the dominance of molluscss along Mangalore section. Prabhu and Reddy (1987) recorded significant density of molluscss in the coastal waters of Baikampady- Suratkal (D.K). Similar dominance of molluscs was observed by Devassy et al. (1987). Studies carried out along South Kanara coast revealed the dominance of molluscs. Gopala krishnan and Nair (1998) and Mohan (1999) observed the dominance of molluscs in the coastal waters of Mangalore. Laxmipathy (2001) documented greater contribution of molluscss to the total macrobenthos collected from inshore waters of Mangalore. Baban et al. (2002) could not observe greater dominance of molluscss in the coastal waters of Dhabol, west coast of India. Similar observation was made by Jayaraj et al., (2007) in Northwest Indian shelf. Spatial distribution molluscss in the present study revealed greater percent contribution at $10 \mathrm{~m}$ depth along all the three sections. In the present study, the higher population of molluscss was found to control the abundance of polychaets and vice versa. Similar observations were made by several authors who have carried out observations in the same area. The phylum Echinodermata represented by Asteroidea, Ophiuroidea and Holoshoridea. At $5 \mathrm{~m}$ depth along Bengre coast number varied from 0 to $240 \mathrm{No} / \mathrm{m}^{2}$ and at $10 \mathrm{~m}$ depth varied from 0 to $350 \mathrm{No} / \mathrm{m}^{2}$, along the Thannirbhavi coast at $5 \mathrm{~m}$ depth number varied from 0 to $20 \mathrm{No} / \mathrm{m}^{2}$ and at depth of $10 \mathrm{~m}$ depth number varied from 0 to $40 \mathrm{No} / \mathrm{m}^{2}$. Along Chitrapur coast at $5 \mathrm{~m}$ depth number varied from 0to $270 \mathrm{No} / \mathrm{m}^{2}$ and at at $10 \mathrm{~m}$ depth varied from 0to $100 \mathrm{No} / \mathrm{m}^{2}$. At $5 \mathrm{~m}$ depth along Bengre coast Ophiuroidea (Bittle star) occurred more frequently than that of $10 \mathrm{~m}$. Along Thannirbhavi coast Ophiuroidea was observed more frequently at $10 \mathrm{~m}$ depth than at $5 \mathrm{~m}$ along Chitrapur they were present more frequently at $10 \mathrm{~m}$ than $5 \mathrm{~m}$. Along these coasts the echinoderms were abundant during pre monsoon season. It is interesting to note Asteroidea and Holoshoridea recorded along Chitrapur section at $10 \mathrm{~m}$ depth. Egg cases were common to very common at $5 \mathrm{~m}$ depth along Bengre and Thannirbhavi coast. They were mostly rare at $10 \mathrm{~m}$ along both the sections. While along Chitrapur most of the time either rare or absent and absent at $5 \mathrm{~m}$ depth. Sporadic occurance of echninoderms was observed by almost all the authors who have worked in the same area. However Laxmipathy (2001) could not observe any Echinoderms in the inshore waters of Mangalore. 


\section{Kumari M.}

From the two way analysis of variance (Table 1) changes. Stations located at $5 \mathrm{~m}$ depth contour off carried out for population density $\left(\mathrm{No} / \mathrm{m}^{2}\right)$ of the coast of Bengre registered dominance of sand macrobenthos after square root transformation, it was found that there was a significant difference between the months and stations.

Organic carbon and sediments characteristics Organic carbon content of sediments (Table 2) varied from 0.02 to $3.36 \%$. And sediment texture in term of percentage of sand, silt and clay has been estimated along all the section at different months are presented in (table 3). In the present investigation, textural characteristics of the sediment exhibited distinct spatial and season followed by silt and clay, whereas along the same coast of $10 \mathrm{~m}$ depth contour, the sediment was dominated by silt followed by sand and clay. Similar trend was found along the coast off Thannirbhavi and Chitrapur. The spatial distribution at 5 meter along the three coast revealed that the silt percentage is always higher in Bengre followed by Chitrapur and Tannirbhavi during postmonsoon while during later half of premonsoon the silt percentage was higher at Tannirbhavi followed by Bengre and Chitrapur.

Table 1. Analysis of variance for population density $\left(\mathrm{No} . / \mathrm{m}^{2}\right)$ of macrobenthos.

\begin{tabular}{|l|c|l|l|l|}
\hline Source of variation & Degree of Freedom & SSQ & MSSQ & F- ratio \\
\hline Due to months & 7 & 5131.701 & 733.1002 & $3.09^{*}$ \\
\hline Due to stations & 5 & 5995.346 & 1199.069 & $5.05^{*}$ \\
\hline Error & 35 & 8296.554 & 237.0558 & \\
\hline Total & 47 & 19424 & & \\
\hline
\end{tabular}

* Significant at 5\% level; $\quad$ SSQ = Sum of squares; MSSQ = Mean Sum of Squares

Table 2. Distrbution of sediment organic carbon (\%) at different stations along Bengre, Thannirbhavi and Chitrapur sections.

\begin{tabular}{|c|c|c|c|c|c|c|c|c|}
\hline \multirow{2}{*}{ Stations } & \multicolumn{4}{|c|}{$\mathbf{2 0 0 6}$} & \multicolumn{5}{c|}{ 2007 } \\
\cline { 2 - 9 } & Oct. & Nov. & Dec. & Jan. & Feb. & Mar. & Apr. & May. \\
\hline B1 & 0.635 & 0.345 & 3.20 & 2.07 & 0.77 & 2.10 & 0.327 & 0.525 \\
\hline B2 & 2.95 & 2.93 & 3.20 & 2.43 & 2.74 & 2.10 & 2.10 & 2.50 \\
\hline T1 & 1.08 & 0.586 & 0.276 & 1.10 & 1.84 & 0.293 & 0.50 & 1.50 \\
\hline T2 & 2.95 & 2.93 & 3.20 & 2.58 & 3.36 & 2.10 & 2.10 & 2.50 \\
\hline C1 & 0.521 & 0.241 & 0.017 & 0.034 & 0.034 & 0.448 & 0.379 & 0.759 \\
\hline C2 & 2.85 & 2.93 & 3.20 & 2.93 & 2.10 & 2.10 & 2.10 & 2.50 \\
\hline
\end{tabular}


Impact of industrial effluent on macrobenthic diversity

Table 3. Distribution of sediment texture (\%) at different stations along Bengre, Thannirbhavi and Chitrapur sections.

\begin{tabular}{|c|c|c|c|c|c|c|c|c|c|}
\hline \multirow[t]{2}{*}{ Period } & \multirow{2}{*}{ Fraction } & \multicolumn{3}{|c|}{2006} & \multicolumn{5}{|c|}{2007} \\
\hline & & Oct. & Nov. & Dec. & Jan. & Feb. & Mar. & Apr. & May. \\
\hline \multirow{3}{*}{ B1 } & SAND & 72.29 & 73.46 & 90.77 & 84.52 & 86.41 & 78.75 & 88.54 & 89.52 \\
\hline & SILT & 27.56 & 26.44 & 9.13 & 15.39 & 13.49 & 21.20 & 11.43 & 10.46 \\
\hline & CLAY & 0.15 & 0.10 & 0.09 & 0.09 & 0.10 & 0.03 & 0.03 & 0.02 \\
\hline \multirow{3}{*}{ B2 } & SAND & 0.30 & 0.37 & 0.46 & 9.62 & 1.88 & 14.98 & 3.22 & 3.90 \\
\hline & SILT & 99.25 & 99.51 & 99.45 & 90.22 & 97.92 & 84.97 & 96.73 & 96.07 \\
\hline & CLAY & 0.45 & 0.12 & 0.09 & 0.16 & 0.20 & 0.04 & 0.05 & 0.04 \\
\hline \multirow{3}{*}{ T1 } & SAND & 87.35 & 89.47 & 93.38 & 86.06 & 83.67 & 86.24 & 86.00 & 86.52 \\
\hline & SILT & 12.56 & 10.48 & 3.35 & 13.38 & 16.26 & 13.68 & 13.94 & 13.44 \\
\hline & CLAY & 0.09 & 0.05 & 3.27 & 0.05 & 0.07 & 0.08 & 0.07 & 0.04 \\
\hline \multirow{3}{*}{$\mathbf{T 2}$} & SAND & 1.10 & 1.11 & 3.96 & 15.55 & 34.27 & 7.21 & 1.57 & 2.43 \\
\hline & SILT & 98.70 & 98.79 & 95.92 & 84.36 & 65.66 & 92.76 & 98.37 & 97.53 \\
\hline & CLAY & 0.20 & 0.10 & 0.12 & 0.09 & 0.07 & 0.03 & 0.06 & 0.04 \\
\hline \multirow{3}{*}{ C1 } & SAND & 86.23 & 87.47 & 96.47 & 95.86 & 96.11 & 92.37 & 94.70 & 95.50 \\
\hline & SILT & 13.69 & 12.49 & 3.50 & 4.05 & 3.84 & 7.16 & 5.26 & 4.46 \\
\hline & CLAY & 0.08 & 0.04 & 0.02 & 0.09 & 0.05 & 0.02 & 0.04 & 0.04 \\
\hline \multirow{3}{*}{$\mathrm{C} 2$} & SAND & 0.14 & 0.16 & 0.66 & 4.17 & 5.58 & 0.43 & 0.57 & 1.27 \\
\hline & SILT & 99.62 & 99.71 & 99.24 & 95.69 & 94.34 & 99.49 & 99.35 & 98.66 \\
\hline & CLAY & 0.24 & 0.13 & 0.10 & 0.14 & 0.08 & 0.08 & 0.08 & 0.07 \\
\hline
\end{tabular}

Along $10 \mathrm{~m}$ depth during pre monsoon season at same depth contour silt percentage was higher at Chitrapur followed by Thannirbhavi and Bengre except during March. From Table 3 it is evident that not only the space, even the season influence the textural characteristics of sediments. Parulekar and Ansari (1981) recognized four types of sediments characteristics such as sand and sandy clay, sand and silty clay, silty clay and clayey silt in estuarine complex of Goa. During the present investigation, the observation made at 5meter depth contour was in agreement with Prabhu (1992), whereas the sediment at 10 meters depth contour was in agreement with Sasamal et al. (1986). From the data gathered it becomes very clear sediment texture at 5 meter depth sandy, silty while 10 meter depth contours it was silty-sandy.

Table 2 shows that organic carbon content in the sediment was higher at $10 \mathrm{~m}$ depth stations along Bengre, Thannirbhavi, Chitrapur whereas it was low at $5 \mathrm{~m}$-depth along the three stations, indicated clearly that organic carbon of the sediment is directly related with sediment texture. The sediment texture characteristics revealed that at $10 \mathrm{~m}$-depth contour, the sediment consists mainly silt and clay, therefore organic carbon content is higher. The relationship is in agreement with the works carried out by above authors (while simply comparing the present sediment organic carbon with that of the values documented by authors 


\section{Kumari M.}

were worked in same area revealed clearly that the present values were higher.) It is interesting to note that even at $5 \mathrm{~m}$ depth along the coast of Bengre; the organic carbon was higher in the month of December and January. At the same depth contour, Thannirbhavi values were higher than that of Chitrapur. This could be due to discharge of untreated domestic sewage through GurpurNetrvathi estuary. From the fig it becomes evident that the parameter could not exhibit any clearcut seasonal variation. Similar seasonal trend was observed by Mohan (1999) along the cost of Panambur and Chitrapur. However values during post monsoon were by and large higher than that of pre monsoon. Nair et al. (1978) and Sahoo (1985) recorded higher organic carbon in the sediment during monsoon and post monsoon season from south canara coast.

\section{Conclusion}

From the present study it can be concluded that macrobenthic organism and textural characteristics of sediment have exhibited seasonal and spatial variation. The macrobenthos were represented by six different groups, namely echiuroids, sipunculoids, polychaetes, crustacean, molluscss and echinodermata. The great abundance and diversity of benthic organisms was observed in the Thannirbhavi, when compare to the Chitrapur. From the data gathered it becomes very clear sediment texture at 5 meter depth sandy-silty while at 10 meter depth contour it was silty- sandy. Silty-clayey sediment harbored higher density of polychaetes where as sandy-silty sediment supported greater abundance of mollsucs. The organic carbon content in the sediment was higher at $10 \mathrm{~m}$ depth whereas it was low at $5 \mathrm{~m}$-depth along the three stations, indicated clearly that organic carbon of the sediment is directly related with sediment texture.

\section{Acknowledgements}

The author thanks the Director of Instruction, College of Fisheries Mangalore for the facilities provided and Prof. R. J. Katti for their cooperation, guidance and encouragement.

\section{References}

Ansari, Z. A., Harkantra, S. N., Nair, S. A., Parulekar, A. H., 1977. Benthos of Bay of Bengal: A preliminary account. Mahasagar, 19( 1\&2): 55-60.

Baban, I., Nimi, R. and Zakir, A. A. 2002. Macrobenthic communities of the coastal waters of Dabhol, west coast of India. Indian Journal of Marine Sciences, 31(2): 9399.

Buchanan, J. B. and Kain, J. M. 1971. Measurement of physical and chemical environment.In: Holme,N, A. and McIntyre, A.D., (Eds). Method for study of Macrobenthos, I. B. P. Handbook, No. 16,Blackwell, Oxford, pp.30-58.

Devassy, V. P. and Gopinath, C. K. 1970. Hydrobiological features of Kerala back waters during pre monsoon and post monsoon months. Fish Technology, 7(2): 190- 194.

Devassy, V. P., Achuthan, C. T. K., Harkantra, S. N. and Nair S. 1987. Effectof industrial effluent on biota; A case study of Mangalore. West coast of India. Indian Journal of Marine Science, 16: 146-50.

El- Wakeeel, S. K. and Reley, J. P. 1957. Determination of organic carbon in marine muds. J. Cans. Pevur. Int. Explor. Mar., 22: 180-183.

Gopalkrishnan, T. C. and Nair Chandrasekharan, K. K. 1998. Subtidal benthic macrofauna of the Mangalore coast, west coast of India. . Indian Journal of Marine Sciences, 27: 351-355.

Harkantra, S. N. and Parulekar A. H. 1994. Soft sediment dwelling macro- invertebrates of Rajpur bay, central west coast of India. Indian Journal of Marine Sciences, 23: 31-34.

Harkantra, S. N. 1982. Studies on sub littoral macrobenthic fauna of the inner Swansea bay. Indian Journal of Marine Sciences, 11: 75-78.

Harkantra, S. N., Ayyapan, N., Ansari, Z. A. and Parulekar, A. H. 1980. Benthos of shelf region along the west coast of India. Indian Journal of Marine Sciences, 9: 106-110.

Jayaraj, K. A., Jayalakshmi, K. V. and Saraladevi, K. 2007. Influence of environmental properties on macrobenthos in the north west Indian shelf. Environmental Monitoring and Assessment, 459-75.

Jayraj, E. G. 1982. Studies on currents and some oceanographic factors in relation to fisheries off Mangalore.M.F.Sc., Thesis. University of Agricultural Sciences, Bangalore.pp:216.

Kurian C. V. 1971. Distribution of benthos on the south-west coast of India In: Fertility of the sea Vol.I. J.DCOSTLOW Jr.(Ed) Gordan and Breach Scientific publication,Newyork:225-239. 
Lakshmipathi, M. T. 2001. Spatial and temporal distribution of benthos in relation to sediment characteristics in the inshores waters of Arabian sea off Mangalore. M.F.Sc., Thesis. University of agricultural Sciences, Bangalore.

Menon, P. G., Madhupratap, M., Haridas, P., Venugopal, P. and Rao, T. S. S. 1979. Faunal composition in polluted nearshore environment. Indian Journal of Marine Sciences, 8: 146-149.

Mohan, K. 1999. Distribution of macrobenthic organisms in relation to the selected sediment characteristics in the Arabian Sea off Chitrapur receiving industrial effluents. M.F.Sc., Thesis. University of Agricultural Sciences, Bangalore.

Nair, R. R., Hashimi, N. H. And Kidawi, R. M. 1978. Topography and sediments of the western continental shelf of India- Vengurla to Mangalore. Indian Journal of Marine Sciences, 794): 224-230.

Parulekar A. H. and Ansari, Z. A. 1981. Benthic macrofauna of the Andaman sea. Indian Journal of Marine Sciences, 10: 280- 284.

Parulekar A. H., Dhargalkar V. K. and Singhal S. Y. S. 1980, Benthic studies in Goa estuaries. Indian Journal of Marine Sciences, 200.

Pillai, N. G. 1977. Distribution and seasonal abundance of macrobenthos of Cochin backwaters. Indian Journal of Marine Sciences, 6: 1-5.

Prabhu, H. V. and Reddy M. P. M. 1987. Macrobenthos and sediment distribution in relation to demersal fish catches off Biakampady- Surathkal, South Kanara coast. Indian Journal of Marine Sciences, 16: 60-64.
Prabhu, H. V. 1992. Sedimentiological and biological studies of sediments off Honnavar, North Kanara, west coast of India. $\mathrm{Ph}$. D. Thesis. Mangalore University, Mangalagangothri, pp. 1-223.

Prabhu, H. V., Narayana, A. C. and Katti, R. J. 1993. Macrobenthic fauna in nearshore sediments off Gangolli, west coast of India. Indian Journal of Marine Sciences, 22: $168-171$

Sahoo, J. K. 1985. Studies on the sediment characteristics in relation to benthos of Talapady lagoon, Mangalore. . M.F.Sc., Thesis. University of Agricultural Sciences, Bangalore.pp 1-177.

Sasamal, S. K., Sahu, B. K. and Panigrahy, R. C. 1986. Textural and composition of sediments of Hoogly estuary and nearshore environment. Indian Journal of Marine Sciences, 15: 201-202.

Satyanarayana, D., Panigraphy, P. K. and Sahu, S. D. 1994. Metal pollution in harbour and coastal sediment of vishakhapattanam, east coast of India. Indian Journal of Marine Sciences, 23: 52-54.

Venkatesh, P. H. and Reddy, M. P. M. 1987. Macrobenthos and sediment distribution in relation to demersal fish catch off Baikampady -Surathkal. South canara coast. Indian Journal of Marine Sciences, 16: 60-64.

Venugopal, P., Devi, S. K., Remani, K. N. and Unnithan, R. V. 1982. Trace metals in the sediments of the Cochin backwaters.Mahasagar, 15(4): 205-214. 